\title{
COVID-19: Why Declining Biodiversity Puts Us at Greater Risk for Emerging Infectious Diseases, and What We Can Do
}

\author{
Aditya K. Khetan, MD (1) \\ Population Health Research Institute, McMaster University Hamilton, ON, Canada.
}

J Gen Intern Med 35(9):2746-7

DOI: $10.1007 / \mathrm{s} 11606-020-05977-\mathrm{x}$

(c) Society of General Internal Medicine 2020

$\mathrm{E}$ merging infectious diseases (EID), which include zoonotic diseases, drug-resistant pathogens, and vectorborne pathogens, have been increasing steadily since $1940 .{ }^{1}$ Most of this increase has been due to zoonotic pathogens from wildlife; common examples of which are HIV, Ebola, SARS, MERS, and, now, COVID-19. For every decade since 1940, there has been a consistent increase in the number of EID events from wildlife-related zoonosis. Human activity is the primary driver of this increase, with loss of biodiversity a leading mechanism. ${ }^{2}$

Biodiversity can be defined as variety in all forms of life-from genes to species to ecosystems. Humans have contributed to species extinction for thousands of years. ${ }^{3}$ Current extinction rates of species are 100-1000 times background extinction rates and future extinction rates (over the next 50 years) are estimated to be 10 to 100 times the present extinction rates. Since 1970, population sizes of birds, mammals, amphibians, reptiles, and fish have declined by almost $30 \%$ and, as of 2020 , $27 \%$ of all assessed species are threatened with extinction. As species move towards extinction, viruses (and other organisms) that survive on those species are under increasing evolutionary pressure to adapt and switch hosts. Ultimately, viruses that can make the switch have an evolutionary advantage. As the number of species in the wild dwindles, an increasing number of viruses develop the potential to "jump" to humans, thus increasing the risk of EID. ${ }^{4}$ When this loss of biodiversity is coupled with close animal-human contact, the virus is able to complete its transmission to humans. COVID-19 is thought to have originated as an enzootic bat virus that switched to humans through an intermediate animal reservoir. The Huanan Seafood Market, with plenty of opportunities for animal-human interaction, provided an enabling platform for such transmission. For Ebola and Nipah viruses, destruction of forests to create palm oil (and in the case of Nipah, also timber) plantations enabled the right conditions for

Received May 6, 2020

Revised May 19, 2020

Accepted June 11, 2020

Published online June 25, 2020 those viruses. Fruit bats serve as a reservoir for both. With respect to Ebola, the fruit bats thrived among the palm oil trees and, when they came into close contact with humans through these plantations, passed on the virus to humans. For Nipah, the fruit bats contaminated date palm sap, which was then consumed by humans who thus got infected.

Given that loss of biodiversity is a primary driver of EID, there is an urgent need for measures to stem this loss. While public health measures, including surveillance of emerging disease hotspots, can be helpful as near-term strategies, they cannot substitute for a long-term solution that conserves biodiversity. In the absence of this, it is likely that public-health capacity will continue to be overwhelmed. Human activities that drive loss of biodiversity are also directly tied to climate change and increasing water scarcity. As a result, targeting such activities can lead to a multitude of planetary health - and ipso facto human health - benefits. ${ }^{5}$ These activities primarily involve agricultural intensification and expansion, which are the primary drivers of deforestation. Human agriculture uses $33 \%$ of earth's available land surface, either as cropland (12\%) or pasture (21\%). It is estimated that between 2000 and 2010 , $70 \%$ of deforestation was attributable to agricultural land expansion. This agricultural land expansion has mostly been for farming animals (for meat and other animal products such as dairy), soybean production, and palm oil production. ${ }^{6}$ Further, over $80 \%$ of soybean is used to feed animals for meat and is the principal source of protein for farmed animals. Soybean demand, therefore, is essentially a surrogate for demand of meat. Currently, $40 \%$ of calories available from global crop production are either fed to animals or used as biofuels. ${ }^{5}$

Given the significant contribution of human meat consumption to loss of biodiversity, decreasing such consumption must be recognized as a major priority for decreasing the incidence of EID over the medium to long term. Such progress will also result in beneficial effects towards combating climate change, reducing water scarcity, and addressing malnutrition. It is estimated that $25 \%$ of global GHG emissions are the result of agriculture, most of it from the farming of animals for human consumption. The water footprint of a serving of meat is $10-20$ times the water footprint of a serving of plant foods. Decreasing the consumption of meat, therefore, can lead to progress in water conservation. ${ }^{7}$ For every gram of protein in beef, $20 \mathrm{~g}$ of protein is utilized in feeding the animal. For chickens, the corresponding figure is $4 \mathrm{~g}$. If the world's soybean production were instead utilized to feed humans directly, there would be a 
several-fold increase in protein availability for a large proportion of humans, whose protein demand is expected to rise with increasing economic prosperity.

It is time we - as an interdependent world - recognize that what we eat primarily determines how the planet is used. Physicians have historically played a leading role in issues that threaten the survival of our species, such as nuclear warfare. But with food, physicians have taken a narrow view in dietary guidelines and focused on isolating the effect of individual foods or nutrients on human health, ignoring the wider ecosystem which our food habits influence, and are, in turn, influenced by. As the latest pandemic shows, such a narrow view has been counterproductive, and likely will continue to cause significant harm. It is time for us to recognize that food, human health, and the environment are deeply interconnected, and understanding these relationships is vital to our planetary health.

Corresponding Author: Aditya K. Khetan, MD; Population Health Research Institute, McMaster University Hamilton, ON, Canada (e-mail: aditya.khetan@phri.ca).

\section{Compliance with Ethical Standards:}

Conflict of Interest: The authors declare that they do not have a conflict of interest.

\section{REFERENCES}

1. Jones KE, Patel NG, Levy MA, Storeygard A, Balk D, Gittleman JL, et al. Global trends in emerging infectious diseases. Nature. 2008;451(7181):990-993.

2. Keesing F, Belden LK, Daszak P, Dobson A, Harvell CD, Holt RD, et al. Impacts of biodiversity on the emergence and transmission of infectious diseases. Nature. 2010;468(7324):647-652.

3. Redford K. Human influences on biodiversity. Glob Biodivers Assess Eds VH Heywood RT Watson. 1995;711-822.

4. Hoberg EP, Brooks DR. Evolution in action: climate change, biodiversity dynamics and emerging infectious disease. Philos Trans R Soc B Biol Sci. 2015;370(1665):20130553.

5. Whitmee S, Haines A, Beyrer C, Boltz F, Capon AG, de Souza Dias BF, et al. Safeguarding human health in the Anthropocene epoch: report of The Rockefeller Foundation-Lancet Commission on planetary health. Lancet. 2015;386(10007):1973-2028.

6. Gibbs HK, Ruesch AS, Achard F, Clayton MK, Holmgren P, Ramankutty $\mathbf{N}$, et al. Tropical forests were the primary sources of new agricultural land in the 1980s and 1990s. Proc Natl Acad Sci. 2010;107(38):16732-16737.

7. Kim BF, Santo RE, Scatterday AP, Fry JP, Synk CM, Cebron SR, et al Country-specific dietary shifts to mitigate climate and water crises. Glob Environ Chang. 2019;101926.

Publisher's Note: Springer Nature remains neutral with regard to jurisdictional claims in published maps and institutional affiliations. 